\title{
Article \\ Organic Matter in Riverbank Sediments and Fluvisols from the Flood Zones of Lower Vistula River
}

\author{
Mirosław Kobierski (D) and Magdalena Banach-Szott* (D)
}

check for

updates

Citation: Kobierski, M.; Banach-Szott,

M. Organic Matter in Riverbank

Sediments and Fluvisols from the

Flood Zones of Lower Vistula River.

Agronomy 2022, 12, 536.

https://doi.org/10.3390/

agronomy12020536

Academic Editors: Ladislav Menšík,

Eva Kunzová and

Lukáš Hlisnikovský

Received: 1 February 2022

Accepted: 18 February 2022

Published: 21 February 2022

Publisher's Note: MDPI stays neutral with regard to jurisdictional claims in published maps and institutional affiliations.

Copyright: (C) 2022 by the authors. Licensee MDPI, Basel, Switzerland. This article is an open access article distributed under the terms and conditions of the Creative Commons Attribution (CC BY) license (https:// creativecommons.org/licenses/by/ $4.0 /)$.
Department of Biogeochemistry and Soil Science, Bydgoszcz University of Science and Technology, 6 Bernardynska St., 85-029 Bydgoszcz, Poland; kobierski@pbs.edu.pl

* Correspondence: mbanach@pbs.edu.pl

\begin{abstract}
The research objective of this study was to determine whether and to what extent the form of use of Fluvisols (arable soil and grassland) of a Lower Vistula floodplain valley (Fordonska Valley, Poland) determined their relative organic matter properties, as compared with nearby riverbank sediments. Riverbank sediments were sampled from a depth of $0-20 \mathrm{~cm}$, and soil samples from 0 to $30 \mathrm{~cm}$, all in three replicates. Basic physico-chemical soil properties were determined: texture, $\mathrm{pH}$, and the contents of total organic carbon (TOC), total nitrogen (TN), dissolved organic carbon (DOC) and dissolved organic nitrogen (DON). Humic acids (HAs) were extracted by the Schnitzer method and analysed to assess their spectrometric parameters in the UV-VIS range and hydrophilic and hydrophobic properties. Riverbank sediment samples contained significantly lower TOC and TN contents than Fluvisols, regardless of land-use type. The TOC, TN, DOC and DON contents and properties of humic acids in the Fluvisol surface layer depended on land-use type, because the arable soils had significantly lower TOC, TN, DOC and DON contents than the grasslands, despite having a similar grain size (texture). Based on the $\mathrm{A}_{2 / 4}, \mathrm{~A}_{2 / 6}, \mathrm{~A}_{4 / 6}$ ratios, it was found that HA molecules isolated from the humus horizon of arable soils had a higher degree of maturity than HAs isolated from grassland soil samples. The spectrometric properties of humic acids isolated from riverbank sediments showed a higher degree of maturity than those from Fluvisols. This research showed that the properties of humic acids in Fluvisols are determined by the quantity and quality of organic matter transported in suspended matter that accumulates annually in flood valleys during flood events. The current land-use type of Fluvisols significantly influenced the properties of organic matter, and thus of humic acids. Therefore, these properties can be used to evaluate the transformation of organic matter that occurs in Fluvisols depending on the type of use.
\end{abstract}

Keywords: Fluvisols; riverbank sediments; humic acids; HPLC; UV-VIS

\section{Introduction}

The most extensive area of river floodplain Fluvisols in Poland is located along the Vistula River, which is characterized by a natural riverbank along its course; the channel is only stabilized in cities and at bridges. Floodplains with Fluvisols play a very important role, both agricultural and ecological, as some are landscape parks. The natural floodplain is delimited by a floodbank and comprises wasteland containing riparian woodlands and is under agricultural use as grasslands and arable land. Floodplain deposits reflect a diversity of mechanisms responsible for sediment transport and deposition, including transfer from the river channel during overbank flow, and as a result of slope wash from terraces and valley sides to distal floodplain parts [1,2]. Manuring practices are the main source of DOC and HS in this watershed where agricultural activity is predominantly focussed. The HS were then transferred to the river systems via runoff, particularly during the spring and autumn floods.

Geomorphological processes occurring in river floodplains affect the rate of development of fluvial landforms and usually involve an increase in the content of fine-grained 
sediments rich in organic matter that accumulate after floodwaters recede [3-7]. Coarsegrained sediments are more heavily deposited in river channels or in their immediate vicinity. Fluvial sediments are deposited in the Lower Vistula floodplains every year, in spring and-less frequently—summer floods [8]. The depositional process can significantly enhance the nutrient pool of mineral sediments and accelerate initial ecosystem processes, including soil formation. The soil material in the zone adjacent to the channel is usually characterized by disturbed layering in the soil profile and a varied content of organic matter $[9,10]$. The quantity and quality of organic matter and grain-size composition may be key variables in the pedogenesis of alluvial soils (pedobiogeomorphological processes) [11] Hoffmann et al. [12] have stressed a significant effect of the depositional environment and sedimentary facies on the content of total organic carbon (TOC), which increases with increasing clay content. Davies-Vollum and Smith [13] identified five factors that affect OM content in deposits on the modern avulsive floodplain: position relative to the avulsion belt, changes in local channel activity, distance from an active channel, presence of alluvial ridges, and developmental stage of avulsion. It is difficult to define unambiguously how soil properties change during inundation in periods of flooding, or to what extent they affect the quantity and quality of organic matter. Marie et al. [14] emphasize the importance of a manuring practice as the main source of DOC and humic substances in watershed. The HS were then transferred to the river systems via runoff, particularly during the spring and autumn floods.

Organic matter is a basic and key soil component [15-17], and plays an important role in, among other things, shaping the quality of the environment and global climate changes [18-21]. When introduced into the soil, the (quantitative) entirety of organic matter participates in the global cycle of environmental carbon. It is therefore a fundamental link in the sequestration of carbon and the release of $\mathrm{CO}_{2}$ into the atmosphere [22].

Humic substances constitute a major component of organic matter [23,24]. They are formed by transformation and decomposition processes collectively known as "humification" [24-26]. The term "humic substances" is used to scientifically describe certain components with complex structures that can be isolated and fractionated in several ways [26]. Humin $(\mathrm{H})$ is the insoluble fraction of humic substances; humic acids (HAs) are the fraction that is soluble under alkaline conditions and fulvic acids (FAs) are the fraction that is soluble under both alkaline and acidic conditions [27].

Humic substances have a number of specific chemical and physical properties, such as: a high sorption capacity [28-30] and high-energy absorption across the entire spectrum, especially in the UV and IR ranges of the electromagnetic spectrum [31-34].

The quality of organic matter is largely determined by the properties of humic acids, which constitute one of its main fractions and thus participate in all soil processes [35-37]. The tests, which, among other things, reflect the nature and origin of humic acids, include: $\mathrm{A}_{280}, \mathrm{~A}_{465}, \mathrm{~A}_{665} \mathrm{UV}-\mathrm{VIS}$ range absorbance values of their solutions, and $\mathrm{A}_{2 / 4}, \mathrm{~A}_{2 / 6}, \mathrm{~A}_{4 / 6}$, $\Delta \log K$ coefficients of absorbance [33,38-42]. These can be used to determine the degree of advancement of the humification of organic materials, as well as changes in the properties of the humic acids that occur due to various anthropogenic factors.

The degree of humification of organic matter is also related to the hydrophilic-hydrophobic properties of humic acids. Woelki et al. [43], Preuße et al. [44] and Dębska et al. [45-47] obtained the separation of HA molecules into hydrophilic (HIL) and hydrophobic (HOB-1 and HOB-2) fractions. The relative proportions of the two fractions determine the solubility of humic acids and, as a result, their migration deep into the soil profile. According to reports in the literature [45], as the degree of humification increases, so too does the share of the hydrophilic fraction in humic acid molecules, while the hydrophobic fraction decreases. Consequently, HA molecules with a higher degree of "maturity" have a higher $\mathrm{HIL} / \Sigma \mathrm{HOB}$ ratio.

Flood events are important because bottom sediments carried out of the river channel affect the physico-chemical and biological properties of floodplain soils, which have a relatively high content of humus $[9,48,49]$. The amount of soil material deposited depends 
on the size and extent of the flood, and on the sediment load transported in the river. The Fluvisols that are formed can both indicate changes taking place within the river and allow changes going on in the entire catchment area to be interpreted, because their properties are the result of geological, pedogenic and anthropogenic factors [9]. The aim of this research was to evaluate the current properties of organic matter in samples of the surface layer of alluvial soils in floodplains annually inundated by floodwaters and in riverbank sediments of the nearby Vistula River channel. The overarching objective was to compare the properties of humic acids extracted from the riverbank sediments against those from the alluvial soils used as arable land and grasslands.

\section{Materials and Methods}

\subsection{Materials}

Samples of sediments and alluvial soils were collected from the Fordońska Valley within the Lower Vistula, protected area of Chełmiński Landscape Park (Figure 1). The Vistula is the longest and largest river in Poland, with a length of $1022 \mathrm{~km}$. The Vistula basin covers 194,424 km². The Vistula has been in its present shape for over the last 14,000 years, after the complete recession of the Scandinavian ice sheet from the area. The research covered floodplain areas between the Vistula channel and a flood embankment $200 \mathrm{~m}$ to $600 \mathrm{~m}$ from the river channel.
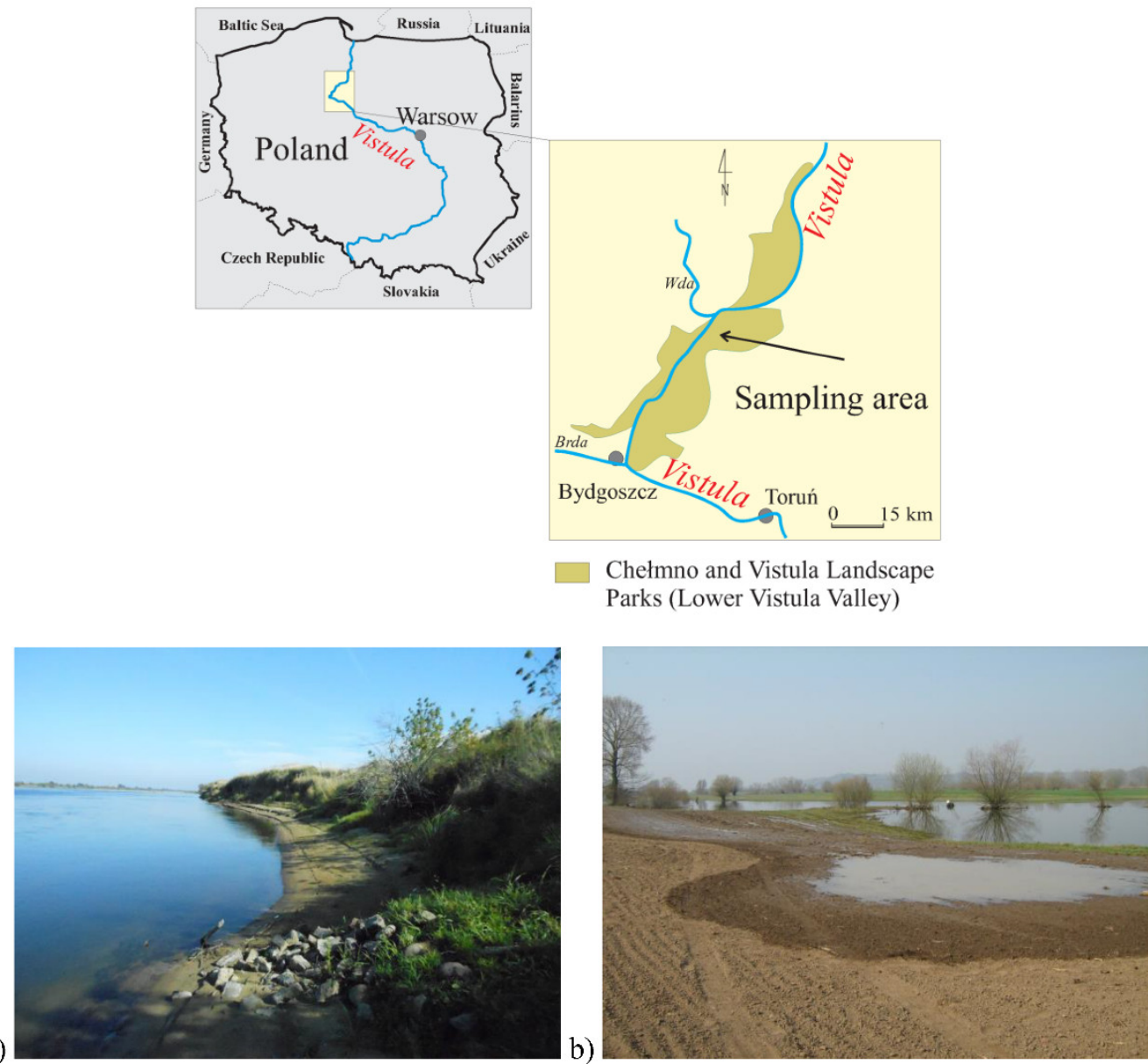

Figure 1. Schematic map and sampling places: (a) riverbank sediments; (b) floodplain.

Fluvisol samples were collected using a spade from a depth of 0-30 $\mathrm{cm}$ in three replicates: ten samples were taken from arable soils and eight from grassland. The distance between the replications was $20 \mathrm{~m}$ in an equilateral triangle and soil samples were taken in a distance within a few kilometres (floodplain). Soil samples were packed into plastic bags 
and transported to a laboratory. Sediment samples were also collected in triplicate, from a depth of $0-20 \mathrm{~cm}$. The sediments samples were similarly pre-treated. The samples were prepared in a laboratory for analysis as follows: plant residue removal, drying at room temperature, grinding, and sieving through a $2.0 \mathrm{~mm}$ mesh.

\subsection{Methods}

2.2.1. Basic Parameters of Soils

The following parameters were assayed:

- The contents of total organic carbon (TOC) and total nitrogen (TN).

The contents of total organic carbon, total nitrogen, dissolved organic carbon (DOC) and dissolved organic nitrogen (DON) were assayed with a Vario Max CN analyser provided by Elementar (Langenselbold, Germany).

The extraction of DOC and DON was performed with $0.004 \mathrm{M} \mathrm{CaCl}_{2}$ for $1 \mathrm{~h}$ at a ratio of the soil to extraction solvent of 1:10 $(w / v)$. The contents of TOC and TN are expressed in

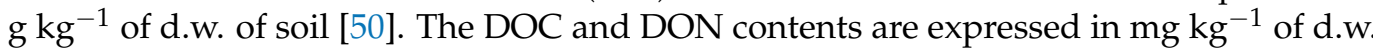
of soil sample [51].

- $\quad \mathrm{pH}$-in the suspension of $1 \mathrm{M} \mathrm{KCl}$;

- The grain-size composition was determined applying the areometric method.

\subsubsection{Extraction and Analyses of Humic Acids}

Humic acids (HAs) were extracted and purified according to standard methods using the following procedure:

Decalcification $(24 \mathrm{~h})$ was achieved with $0.05 \mathrm{M} \mathrm{HCl}(1: 10 w / v)$. After centrifugation, the residue was washed with distilled water until neutral.

Extraction $(24 \mathrm{~h})$ of the remaining solid was carried out with $0.5 \mathrm{M} \mathrm{NaOH}(1: 10 w / v)$, with occasional mixing, followed by centrifugation.

Precipitation $(24 \mathrm{~h})$ of HAs was carried out from the resulting alkaline extract with $2 \mathrm{M} \mathrm{HCl}$ to $\mathrm{pH}=2$ and centrifugation.

The purification of the resulting HAs was carried out as follows: the humic acid residue was treated with a mixture of $\mathrm{HCl} / \mathrm{HF}\left(950 \mathrm{~mL} \mathrm{H}_{2} \mathrm{O}, 5 \mathrm{~mL} \mathrm{HCl}, 5 \mathrm{~mL} \mathrm{HF}\right)$ over a $24 \mathrm{~h}$ period, followed by centrifugation. This procedure was performed three times. The HA residue was treated with distilled water until zero reaction with chloride was achieved.

The preparations were lyophilized and powdered in agate mortar. The ash content in the HA preparations was lower than $2 \%$.

In the separated humic acids, the following determinations were made:

Hydrophilic and hydrophobic properties were determined with a liquid chromatograph HPLC Series 200 with a DAD detector from Perkin-Elmer, Shelton, USA. The separation involved the use of column X-Terra C18, $5 \mu \mathrm{m}, 250 \times 4.6 \mathrm{~mm}$. The solutions of humic acids were applied in $0.01 \mathrm{~mol} / \mathrm{L} \mathrm{NaOH}$ of the concentration of $2 \mathrm{mg} \mathrm{L}^{-1}$; injection of the sample-100 $\mu \mathrm{L}$; solvent: acetonitrile-water; solvents flowed into the gradient (ratio of $\mathrm{H}_{2} \mathrm{O}$ : $\mathrm{ACN}(v / v)$ over 0-6 min-99.5:0.5; 7-13 min-70:30; 13-20 min-10:90); and detection - at a wavelength of $254 \mathrm{~nm}$. Based on the determined areas under the peaks, the share of hydrophilic (HIL) and hydrophobic $(\Sigma \mathrm{HOB}=\mathrm{HOB} 1+\mathrm{HOB} 2)$ fractions in humic acid molecules and the parameter HIL/ $\Sigma$ HOB were determined [43-45].

UV-VIS absorption spectra (Perkin Elmer UV-VIS Spectrometer, Lambda 20, Ueberlingen, Germany): VIS spectra were obtained from $0.02 \%$ humic acid solutions in $0.1 \mathrm{M}$ $\mathrm{NaOH}$ and UV spectra were obtained after fivefold dilution. The absorbances measured at $280 \mathrm{~nm}\left(\mathrm{~A}_{280}\right), 400 \mathrm{~nm}\left(\mathrm{~A}_{400}\right), 465 \mathrm{~nm}\left(\mathrm{~A}_{465}\right), 600 \mathrm{~nm}\left(\mathrm{~A}_{600}\right)$ and $665 \mathrm{~nm}\left(\mathrm{~A}_{665}\right)$ were used to calculate coefficient values:

$\mathrm{A}_{2 / 4}-280 \mathrm{~nm}$ and $465 \mathrm{~nm}$ absorbance ratio;

$\mathrm{A}_{2 / 6}-280 \mathrm{~nm}$ and $665 \mathrm{~nm}$ absorbance ratio;

$\mathrm{A}_{4 / 6}-465 \mathrm{~nm}$ and $665 \mathrm{~nm}$ absorbance ratio;

$\Delta \log \mathrm{K}=\log \mathrm{A}_{400}-\log \mathrm{A}_{600}$ (Kumada 1988). 
Susceptibility to oxidation was determined with hydrogen peroxide through the measurement of decreased HA solutions' absorbance $\left(0.02 \%\right.$ HAs and $1.5 \% \mathrm{H}_{2} \mathrm{O}_{2}$ in $0.1 \mathrm{M}$ $\mathrm{NaOH}$ ), at the wavelength of $465 \mathrm{~nm}$ (Perkin Elmer UV-VIS Spectrometer, Lambda 20, Ueberlingen, Germany). The susceptibility to oxidation was calculated from the following formula:

$$
\Delta \mathrm{A}_{\mathrm{u}} 465=\frac{\mathrm{A}_{0}-\mathrm{A}_{\mathrm{u}}}{\mathrm{A}_{0}} \cdot 100 \%
$$

where: $\mathrm{A}_{0}$-initial absorbance (prior to adding $\mathrm{H}_{2} \mathrm{O}_{2}$ ); $\mathrm{A}_{\mathrm{u}}$-absorbance after oxidation.

\subsubsection{Statistical Analysis}

The soil properties were determined with descriptive statistics: arithmetic mean, minimum value, maximum value, standard deviation, and coefficient of variation. The tables present the mean values from three replications. The statistical analyses of humic acids involved an analysis of variance. The significance of differences was evaluated using Tukey's test. Pearson's correlation was also analysed at a significance level of $p<0.05$. The statistical analyses were performed using the Statistica MS 12.0 software (StatSoft Inc., Tulsa, OK, USA).

\section{Results and Discussion}

\subsection{Basic Soil Parameters}

The right bank of the Vistula regularly breaks in many places, and the amount of sediments deposited on the floodplain depends on the extent of the floodplain and local landscape conditions. The erosion processes observed in the river channel involve the loss of fine sediments at the footslope of the riverbanks during strong currents, especially spring floods. A greater amount of coarse sediments-gravel and sand-are transported by the river and deposited in the river channel. However, as a flood recedes, fine sediment (silt and clay fraction) transported along the river accumulates on the floodplain [8]. Therefore, the studied riverbank sediments differed significantly from the Fluvisols in the percentage of sand, silt, and clay fractions $(p=0.0001)$ (Table 1$)$.

Table 1. The analysis of variance (ANOVA) with Tukey test.

\begin{tabular}{|c|c|c|c|c|c|c|}
\hline Parameter & $\begin{array}{l}\text { Riverbank } \\
\text { Sediments } \\
(n=10)\end{array}$ & $\begin{array}{l}\text { Fluvisols } \\
(n=18)\end{array}$ & $p^{*}$ & $\begin{array}{l}\text { Arable } \\
\text { Soils } \\
(n=10)\end{array}$ & $\begin{array}{l}\text { Grassland } \\
\text { Soils } \\
(n=8)\end{array}$ & $p^{*}$ \\
\hline TOC $\left(\mathrm{g} \mathrm{kg}^{-1}\right)$ & 14.4 & 21.4 & $0.008 *$ & 16.1 & 28.1 & 0.0003 * \\
\hline $\mathrm{TN}\left(\mathrm{g} \mathrm{kg}^{-1}\right)$ & 1.33 & 2.06 & $0.008^{*}$ & 1.6 & 26.3 & $0.004^{*}$ \\
\hline TOC/TN & 11.5 & 10.5 & 0.12 & 10.2 & 10.9 & 0.218 \\
\hline $\mathrm{pH}$ & 7.31 & 6.78 & $0.015^{*}$ & 6.86 & 6.67 & 0.52 \\
\hline Sand (\%) & 82.3 & 35.9 & 0.0001 * & 38.4 & 32.9 & 0.53 \\
\hline Silt (\%) & 12.0 & 44.9 & 0.0001 * & 43.9 & 46.1 & 0.74 \\
\hline Clay (\%) & 5.7 & 19.2 & $0.0001 *$ & 17.7 & 21.0 & 0.20 \\
\hline $\mathrm{DOC}\left(\mathrm{g} \mathrm{kg}^{-1}\right)$ & 0.62 & 0.84 & 0.36 & 0.55 & 1.20 & $0.01 *$ \\
\hline $\mathrm{DON}\left(\mathrm{mg} \mathrm{kg}^{-1}\right)$ & 44.8 & 54.2 & 0.48 & 44.9 & 65.7 & 0.038 \\
\hline$A_{2 / 4}$ & 7.02 & 7.73 & $0.01 *$ & 7.36 & 8.19 & 0.0009 * \\
\hline $\mathrm{A}_{2 / 6}$ & 34.0 & 45.7 & 0.0004 * & 41.5 & 50.8 & 0.0005 * \\
\hline $\mathrm{A}_{4 / 6}$ & 4.82 & 5.88 & 0.0002 * & 5.63 & 6.20 & 0.0007 * \\
\hline$\Delta \mathrm{A}_{\mathrm{u}} 465(\%)$ & 57.3 & 54.0 & 0.122 & 51.2 & 57.5 & $0.002 *$ \\
\hline
\end{tabular}


The Fluvisols had significantly higher contents of silt and clay fractions. The results confirm previous studies of soils of the Lower Vistula floodplains [52-54]. Simansky [55] reports that differences in the chemistry and physical properties of Fluvisols have been significantly affected mainly by their use and soil management practices but not as a consequence of the flow gradient along the river.

The fluvial sediments transported by the river to the floodplain valley are rich in organic matter. The TOC content in riverbank sediments was variable, as indicated by the high coefficient of variation $\left(\mathrm{CV}=73.4 \%\right.$ ) and averaged $14.4 \mathrm{~g} \mathrm{~kg}^{-1}$ (Table 2). The highest mean TOC content was found in samples of soils used as grasslands, at $28.1 \mathrm{~g} \mathrm{~kg}^{-1}$. A significant difference was observed in mean TOC content between arable lands and grasslands $(p=0.0003)$ (Table 1$)$. A similar trend was observed in nitrogen content. The average TOC/TN ratio in riverbank sediments was 11.5 , while in the floodplain soils it was 10.5 (Table 1). Despite the significant differences in mean TOC and TN contents in arable lands and grasslands, the TOC/TN ratios were similar, amounting to 10.2 and 10.9 , respectively.

Table 2. Values of $\mathrm{pH}$ and the organic matter properties.

\begin{tabular}{|c|c|c|c|c|c|c|}
\hline Parameters & $\begin{array}{l}\text { pH } \\
\text { (1 M KCl) }\end{array}$ & $\begin{array}{l}\text { TOC } \\
\left(\mathrm{g} \mathrm{kg}^{-1}\right)\end{array}$ & $\begin{array}{l}\mathrm{TN} \\
\left(\mathrm{g} \mathrm{kg}^{-1}\right)\end{array}$ & TOC/TN & $\begin{array}{l}\text { DOC } \\
\left(\mathrm{g} \mathrm{kg}^{-1}\right)\end{array}$ & $\begin{array}{l}\text { DON } \\
\left(\mathrm{mg} \mathrm{kg}^{-1}\right)\end{array}$ \\
\hline \multicolumn{7}{|c|}{ Riverbank sediments $(n=10)$} \\
\hline Min. & 7.05 & 5.7 & 0.2 & 9.5 & 0.19 & 13.5 \\
\hline Max. & 7.43 & 37.2 & 3.9 & 14.3 & 1.68 & 121.0 \\
\hline Mean & 7.31 & 14.4 & 1.3 & 11.5 & 0.62 & 44.8 \\
\hline SD & 0.14 & 10.57 & 1.07 & 1.87 & 0.54 & 39.81 \\
\hline CV (\%) & 1.9 & 73.4 & 82.3 & 16.3 & 87.1 & 88.9 \\
\hline \multicolumn{7}{|c|}{ Arable soils $(n=10)$} \\
\hline Min. & 5.52 & 12.2 & 1.2 & 9.1 & 0.34 & 33.6 \\
\hline Max. & 7.39 & 20.1 & 2.1 & 12.4 & 0.82 & 58.0 \\
\hline Mean & 6.86 & 16.1 & 1.6 & 10.2 & 0.55 & 44.9 \\
\hline SD & 0.56 & 3.00 & 0.35 & 0.99 & 0.17 & 8.41 \\
\hline CV (\%) & 8.2 & 16.6 & 21.9 & 9.7 & 30.9 & 18.7 \\
\hline \multicolumn{7}{|c|}{ Grassland soils $(n=8)$} \\
\hline Min. & 5.71 & 21.9 & 1.9 & 9.50 & 0.75 & 43.7 \\
\hline Max. & 7.20 & 41.9 & 4.4 & 12.7 & 2.64 & 118.8 \\
\hline Mean & 6.67 & 28.1 & 2.64 & 10.9 & 1.20 & 65.7 \\
\hline $\mathrm{SD}$ & 0.57 & 6.45 & 0.85 & 1.17 & 0.65 & 26.20 \\
\hline CV (\%) & 8.5 & 22.9 & 32.2 & 10.7 & 54.2 & 39.9 \\
\hline
\end{tabular}

SD—standard deviation; CV-coefficient of variation.

The $\mathrm{pH}$ values for riverbed sediments ranged from 7.05 to 7.43 and varied inconsiderably, as confirmed by the very low coefficient of variation (CV) (Table 2). Arable land and grasslands had similar $\mathrm{pH}$ values $(p=0.52)$ (Table 1$)$.

It should be noted that the soil organic matter contains initial materials at different stages of decomposition and large-molecule compounds of specific properties. From an ecological point of view, the fraction of organic matter soluble in water or in salt solutions of $\mathrm{pH}=7$ (DOM) is of great importance.

The mean DOC content was $0.62 \mathrm{~g} \mathrm{~kg}^{-1}$ in riverbank sediments with a high coefficient of variation of $87.1 \%, 0.55 \mathrm{~g} \mathrm{~kg}^{-1}$ with $\mathrm{CV}=30.9 \%$ in arable soils, and $1.20 \mathrm{~g} \mathrm{~kg}^{-1}$ with $\mathrm{CV}=54.2 \%$ in grasslands (Table 2 ). The soils of the floodplain valleys varied significantly in the content of this fraction of organic carbon $(p=0.01)$ (Table 1$)$. The fact that the average 
DOC content was the lowest in arable soils may result from the cultivation treatments conducted. According to Anger et al. [56] and Smreczak and Ukalska-Jaruga [57], in agricultural soils, the DOC content depends mainly on the type of organic material introduced into the soil. Agricultural practices can often reduce the DOC content in soil. Similar results were presented by Banach-Szott et al. [53]. Higher mean DOC contents in the riverbank sediments compared with their contents in the surface layer of Fluvisols were noted.

The DOC content in the studied riverbank sediments and Fluvisols was positively correlated with TOC content (Table 3). According to Watanabe et al. [58], DOC concentrations are linearly correlated with HS concentrations, and are thus directly associated with soil-derived organic matter inputs. It is worth mentioning that in riverbank sediments a significantly positive correlation between the clay fraction and DOC content was noted (Table 3). The impact of flood events on HS distribution was also observed by Marie et al. [14].

Table 3. Pearson linear correlation coefficient values, $p<0.05$, in riverbank sediments $(n=10)$.

\begin{tabular}{|c|c|c|c|}
\hline Parameters & DOC & $\Delta \mathrm{A}_{\mathrm{u}} 465$ & HIL \\
\hline \multicolumn{4}{|c|}{ Riverbank sediments $(n=10)$} \\
\hline TOC & $0.97 *$ & - & - \\
\hline DOC & - & - & - \\
\hline Clay & $0.70 *$ & - & \\
\hline \multicolumn{4}{|c|}{ Arable soils $(n=10)$} \\
\hline TOC & $0.95 *$ & - & - \\
\hline DOC & - & - & - \\
\hline Clay & - & - & 0.75 * \\
\hline \multicolumn{4}{|c|}{ Grassland soils $(n=8)$} \\
\hline TOC & $0.96 *$ & - & 0.86 * \\
\hline DOC & - & - & 0.78 * \\
\hline Clay & - & $-0.82 *$ & - \\
\hline
\end{tabular}

Comparing DON contents between riverbank sediments and Fluvisols, the relationship was similar as for DOC content (Table 1). The average DON content in riverbank sediments was $44.8 \mathrm{mg} \mathrm{kg}^{-1}$, with a high coefficient of variation of $88.9 \%$ (Table 2). The land-use type was determined by the amount of DON in the surface layer of the tested Fluvisols: arable soil-44.9 $\mathrm{mg} \mathrm{kg}^{-1}$; grasslands—65.7 $\mathrm{mg} \mathrm{kg}^{-1}(p=0.038)$ (Table 1).

The contents of TOC, TN, DOC and DON in the studied riverbank sediments were highly differentiated, as confirmed by the high coefficients of variation (Table 2).

The results confirm previous reports in the literature that the soil-use type significantly determines the share of the soluble fraction of organic matter $[53,59]$.

\subsection{Hydrophilic and Hydrophobic Nature of Humic Acids}

Humic acid molecules are composed of both hydrophilic and hydrophobic structures. Using the HPLC method, HAs can be separated into hydrophilic (HIL) and hydrophobic (HOB) fractions $[43,44,53,60]$. The HA molecules isolated from riverbank sediments and Fluvisols had a similar mean share of HIL fractions, at $46.1 \%$ and $46.8 \%$, respectively (Figure 2). The share of HOB fractions was higher, ranging from 53.2\% for the humic acids of grasslands and arable soils to $53.9 \%$ for the humic acids of riverbank sediments. The $\mathrm{HIL} / \Sigma \mathrm{HOB}$ ratios are a consequence of changes in the shares of the discussed fractions. According to Dębska et al. [46] and Kobierski et al. [54], the HIL/ $\Sigma$ HOB parameter is related to the degree of humification of organic matter. The parameter value increases as the degree of maturity of HA molecules increases. HA molecules isolated from riverbank sediments 
and Fluvisols had similar hydrophilic-hydrophobic properties (at $p=0.329$ ) (Figure 3). Despite the lack of significant differences between the values of the HIL $/ \Sigma \mathrm{HOB}$ ratio, HA molecules isolated from riverbank sediments had the lowest values of this parameter (0.860), and the HAs of grasslands the highest values (0.894) (Figure 3). Lower values of the $\mathrm{HIL} / \Sigma \mathrm{HOB}$ ratio indicate the presence of HA molecules characterized by a higher degree of aliphaticity, lower molecular weight and the presence of simple aromatic structures [46]. Both the share of HIL and HOB fractions and the value of the HIL/ $\Sigma$ HOB ratio indicate that humic acids isolated from riverbank sediments showed a higher content of humic substances in an advanced stage of decomposition than the arable land and grassland HA molecules. It is also worth emphasizing that the HIL/ $\Sigma \mathrm{HOB}$ values obtained for humic acids in arable soils and grasslands by Banach-Szott et al. [53] were lower, ranging from 0.75 to 0.77 . This means that the tested HA molecules had a slightly higher degree of maturity. The relative proportions of the two fractions determine the solubility of humic acids and, as a result, their migration deep into the soil profile. This was the most visible for the HA molecules isolated from grasslands, for which the share of the HIL fraction was found to correlate positively with the contents of DOC and TOC (Table 3). In turn, the humic acids isolated from arable soils were characterized by a positive correlation between the share of the HIL fraction and the content of the clay fraction (Table 3).

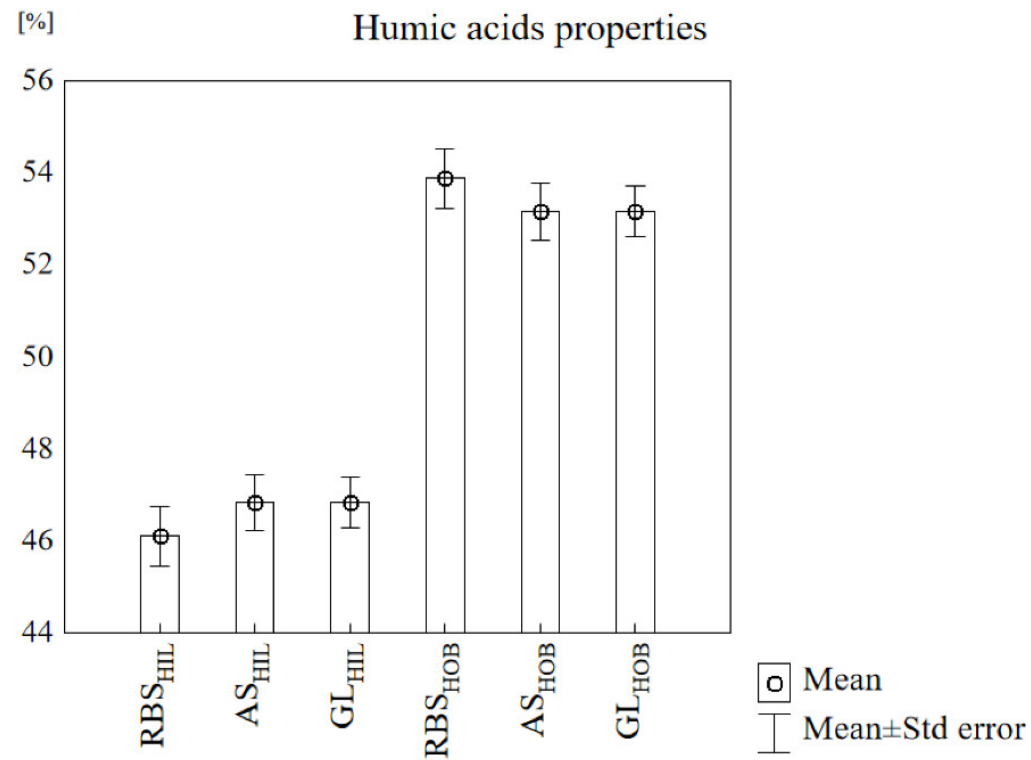

Figure 2. The percentage share of hydrophilic (HIL) and hydrophobic (HOB) fractions in humic acids isolated from riverbank sediments (RBS), arable soils (AS) and grassland soils (GL).

\subsection{Spectrometric Parameters of Humic Acids in the UV-VIS Range}

The HA molecules isolated from grasslands had the lowest intensity absorbance at wavelengths of $280 \mathrm{~nm}\left(\mathrm{~A}_{280}\right), 465 \mathrm{~nm}\left(\mathrm{~A}_{465}\right)$ and $665 \mathrm{~nm}\left(\mathrm{~A}_{665}\right)$, being 3.66, 0.448 and 0.072, respectively (Table 4). The highest absorbance value of 3.99 was at $280 \mathrm{~nm}$, reflecting the content of lignin-type compounds, and was obtained for the humic acids in the arable soils. It is also worth noting that, for the HA molecules isolated from riverbank sediments, the highest degree of humification was obtained, as evidenced by the absorbance values at $665 \mathrm{~nm}$, being 0.118 . 
Properties of humic acids

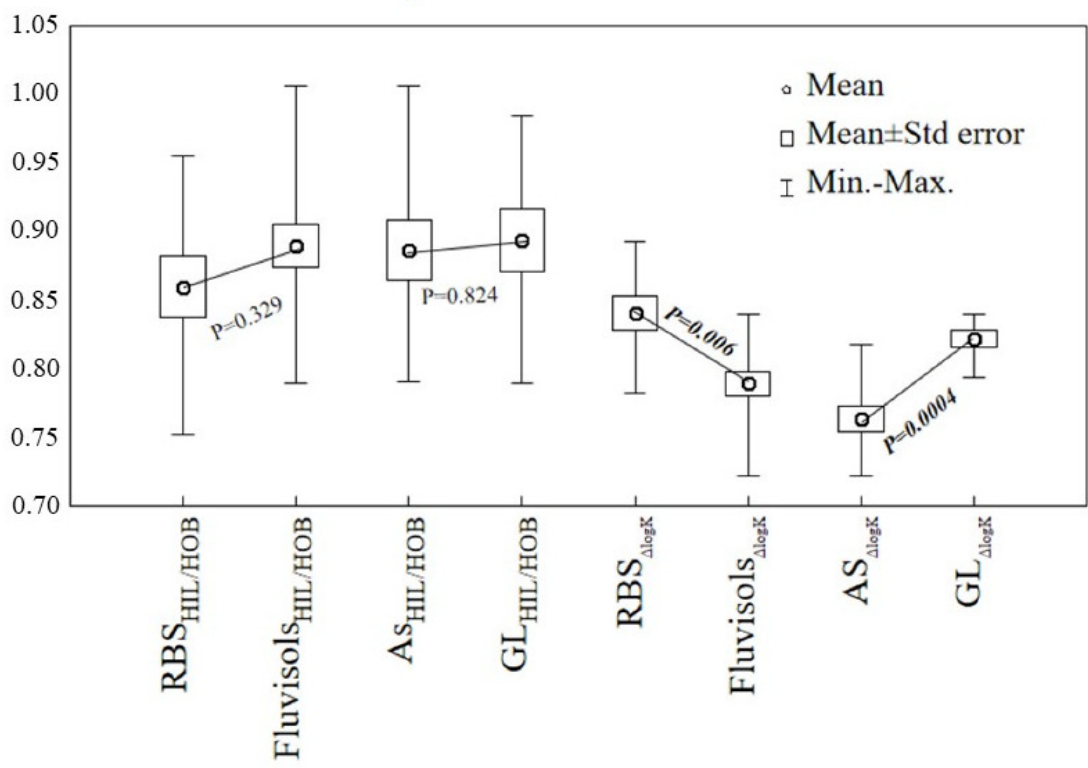

Figure 3. The hydrophilic-hydrophobic properties and parameters $\Delta \log \mathrm{K}$ in humic acids isolated from riverbank sediments (RBS), arable soils (AS) and grassland soils (GL).

Table 4. Spectrometric properties of humic acids in the UV-VIS range of arable soils.

\begin{tabular}{|c|c|c|c|c|c|c|c|c|c|}
\hline Parameters & $\mathbf{A}_{280}$ & $\mathbf{A}_{400}$ & $\mathrm{~A}_{465}$ & $A_{600}$ & $\mathbf{A}_{665}$ & $A_{2 / 4}$ & $A_{2 / 6}$ & $\mathbf{A}_{4 / 6}$ & $\Delta \mathrm{A}_{\mathrm{u}} 465$ \\
\hline \multicolumn{10}{|c|}{ Riverbank sediments $(n=10)$} \\
\hline Min. & 3.40 & 1.03 & 0.460 & 0.132 & 0.081 & 6.45 & 25.5 & 3.88 & 48.2 \\
\hline Max. & 4.67 & 1.34 & 0.679 & 0.221 & 0.146 & 8.21 & 46.6 & 5.68 & 64.2 \\
\hline Mean & 3.91 & 1.21 & 0.561 & 0.177 & 0.118 & 7.02 & 34.0 & 4.82 & 57.3 \\
\hline SD & 0.36 & 0.11 & 0.07 & 0.03 & 0.02 & 0.55 & 6.09 & 0.59 & 4.56 \\
\hline $\mathrm{CV}(\%)$ & 9.2 & 9.1 & 12.5 & 16.9 & 16.9 & 7.8 & 17.9 & 12.2 & 7.9 \\
\hline \multicolumn{10}{|c|}{ Arable soils $(n=10)$} \\
\hline Min. & 3.09 & 0.073 & 0.373 & 0.111 & 0.061 & 6.68 & 35.3 & 5.17 & 47.1 \\
\hline Max. & 4.51 & 1.180 & 0.633 & 0.207 & 0.113 & 8.27 & 20.8 & 6.14 & 56.1 \\
\hline Mean & 3.99 & 0.961 & 0.545 & 0.178 & 0.098 & 7.36 & 41.5 & 5.63 & 51.2 \\
\hline SD & 0.41 & 0.318 & 0.070 & 0.028 & 0.015 & 0.492 & 4.95 & 0.31 & 2.93 \\
\hline CV $(\%)$ & 10.3 & 33.1 & 12.8 & 15.7 & 15.3 & 6.7 & 11.9 & 5.5 & 5.7 \\
\hline \multicolumn{10}{|c|}{ Grassland soils $(n=8)$} \\
\hline Min. & 3.05 & 0.706 & 0.350 & 0.103 & 0.056 & 7.98 & 47.0 & 5.84 & 52.5 \\
\hline Max. & 3.94 & 0.970 & 0.489 & 0.152 & 0.081 & 8.73 & 54.8 & 6.59 & 64.8 \\
\hline Mean & 3.66 & 0.893 & 0.448 & 0.135 & 0.072 & 8.19 & 50.8 & 6.20 & 57.5 \\
\hline SD & 0.32 & 0.085 & 0.046 & 0.016 & 0.009 & 0.25 & 2.76 & 0.24 & 4.00 \\
\hline CV (\%) & 8.7 & 9.5 & 10.3 & 11.8 & 12.5 & 3.0 & 5.4 & 3.9 & 6.9 \\
\hline
\end{tabular}

SD—standard deviation; $\mathrm{CV} —$ coefficient of variation.

As reported by Kumada [38], Tinoco et al. [61] and Filcheva et al. [62], lower values of absorbance and higher values of the $\mathrm{A}_{2 / 4}, \mathrm{~A}_{2 / 6}, \mathrm{~A}_{4 / 6}$ and $\Delta \log \mathrm{K}$ coefficients point to a chemical "young age" of HAs. Young humic acids show a lower degree of condensation of aromatic structures and a lower molecular weight, as compared with the HAs with a high 
degree of humification. As shown in the data presented in Tables 1 and 4 and in Figure 3, the molecules of HAs differed in their degree of maturity.

The $A_{2 / 4}, A_{2 / 6}, A_{4 / 6}$ ratio values were significantly lower for the HAs isolated from riverbank sediments than for the Fluvisols' humic acids (Table 1). This evidences the highest level of humification among the HA molecules. It is worth noting that the humic acids of the grasslands had a lower degree of humification than did those of the arable soils-with significantly higher values of $A_{2 / 4}, A_{2 / 6}, A_{4 / 6}$ (Table 1). The obtained relationships between the values of the ratio $A_{4 / 6}$ from $A_{2 / 4}$ confirmed that the method of soil use determined the spectrometric properties of HAs (Figure 4).

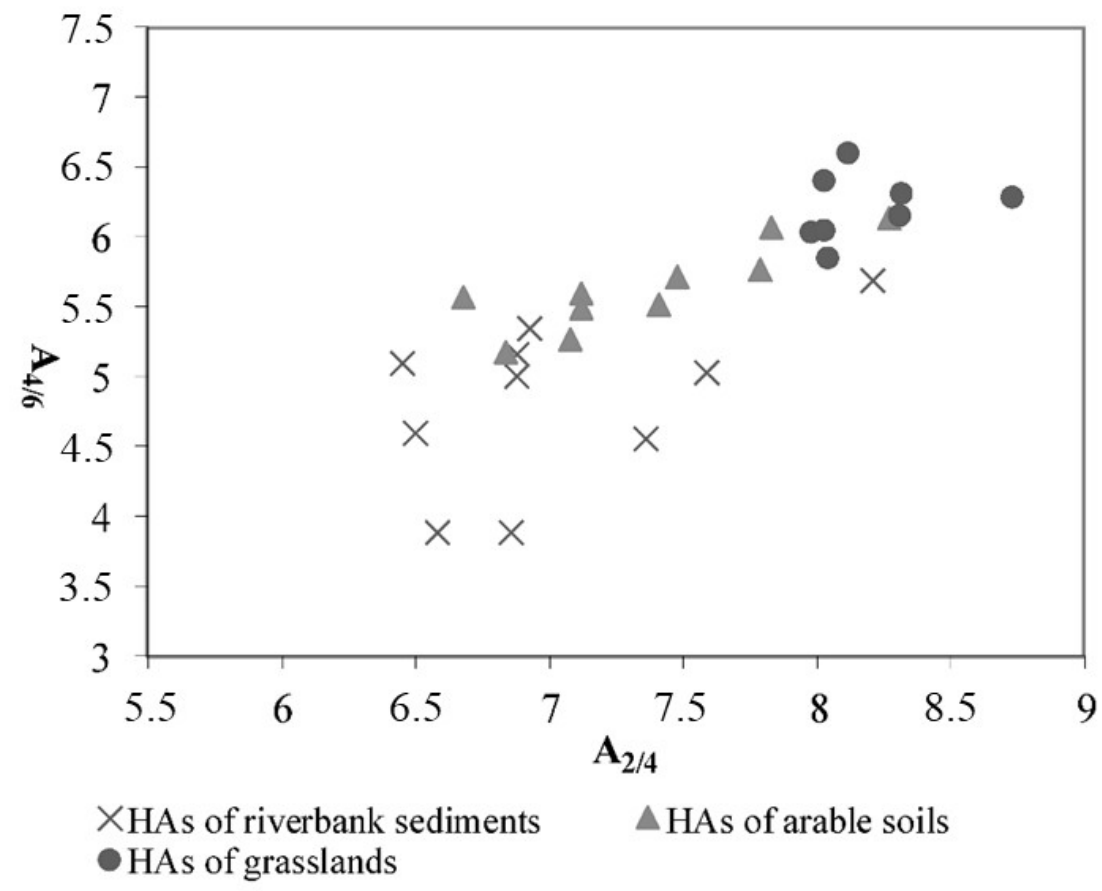

Figure 4. Dependency diagram of the values $\mathrm{A} 4 / 6$ on $\mathrm{A} 2 / 4$ ratio in the molecules of humic acids (HAs).

The higher $\mathrm{A}_{4 / 6}$ ratio values obtained for the analysed HAs of grasslands reflect a lower content of humic substances at the initial decomposition stage as compared with the HAs of arable soils. Morán Vieyra et al. [41] indicated that the $\mathrm{A}_{4 / 6}$ ratio value is higher for non-humified material due to the presence of proteins and carbohydrates. According to Albrecht et al. [63], a high $\mathrm{A}_{4 / 6}$ ratio reflects a low degree of condensation of aromatic compounds. The $\mathrm{A}_{4 / 6}$ ratio values for the HA molecules from the riverbank sediments were similar to those obtained by Polak et al. [42]. For humic acids isolated from sediments of $0.8 \mathrm{~m}$ depth collected from Goczałkowice Reservoir, the authors obtained a ratio in the range of 3.35 to 5.22. Meanwhile, the $\mathrm{A}_{2 / 4}, \mathrm{~A}_{2 / 6}, \mathrm{~A}_{4 / 6}$ and $\Delta \log \mathrm{K}$ absorbance coefficient values for the humic acids isolated from the grasslands were much higher than those obtained by Drag et al. [59] for HA molecules of meadow soil. Furthermore, Kobierski et al. [54], in a study of the humic acids of soils collected from a floodplain between the Vistula riverbed (Poland) and a flood embankment, obtained higher absorbance coefficient values than those for the HAs isolated from arable soils and riverbank sediments and tested herein. This confirms the high degree of transformation of the organic matter of the investigated arable soils and riverbank sediments and evidences the high quality of the humus. The results of the spectrometric analysis of the HAs were also consistent with the DOC content being higher in grasslands than in arable soils.

The susceptibility of humic acids to oxidation with the participation of $\mathrm{H}_{2} \mathrm{O}_{2}$ is measured by changes in the absorbance values of humic acids at a wavelength of $465 \mathrm{~nm}$. It was shown that, as a result of reaction with $\mathrm{H}_{2} \mathrm{O}_{2}$, HA molecules had significantly lower 
absorbance values at this $465 \mathrm{~nm}$ wavelength compared to the absorbance values obtained before the reaction.

HA molecules isolated from arable soils exhibited the lowest susceptibility to oxidationwith a mean of $51.2 \%$ (Table 1 ). Similar average values of susceptibility to oxidation, at the level of $57.3-57.5 \%$, were obtained for humic acids extracted from grasslands and riverbank sediments (Table 1). According to Drag et al. [59], the aliphatic part of humic acid molecules is more susceptible to oxidation, while the aromatic part is more resistant. This is confirmed by the significant differences between arable land and grassland humic acids $(p=0.002)$. The analysis of variance between the susceptibility to oxidation of HAs from riverbank sediments and those from Fluvisols did not confirm the relationship seen in the $A_{2 / 4}, A_{2 / 6}$, $\mathrm{A}_{4 / 6}$ absorbance coefficients (Table 1).

The humic acids extracted from grasslands showed a significantly negative correlation between susceptibility to oxidation and the participation of clay $(\mathrm{r}=-0.82, p=0.05)$ (Table 3).

Based on previous results of studies conducted depending on the distance from the riverbed [53], all Fluvisol samples for the current study were collected from a depth of between 200 and $600 \mathrm{~m}$ from the river channel, because the sampling zonality affected the properties of humic acids.

\section{Conclusions}

The riverbank sediment samples differed significantly from the Fluvisols in basic parameters such as TOC, TN and grain-size distribution. The properties of the Fluvisols of the Lower Vistula valley were determined by the land use the soils were subjected to. Arable soils had lower contents of TOC, TN, DOC and DON than did grassland soils.

The UV-VIS spectrometric properties of the humic acids isolated from riverbank sediments show them to be more mature than the humic acids isolated from Fluvisols.

The degree of maturity of humic acid molecules also depended on the type of land use. The humic acid molecules isolated from arable soils had a higher degree of humification than did the HA molecules isolated from grasslands.

Author Contributions: Conceptualization, M.B.-S. and M.K.; data curation, M.K. and M.B.-S.; formal analysis, M.K. and M.B.-S.; funding acquisition, M.K.; investigation, M.B.-S. and M.K.; methodology, M.K. and M.B.-S.; writing—original draft, M.K. and M.B.-S.; writing—review and editing, M.K. and M.B.-S. All authors reviewed the manuscript. All authors have read and agreed to the published version of the manuscript.

Funding: The research was made as part of 2716/B/P01/2011/40 research project, financed by the Ministry of Science and Higher Education (Poland).

Institutional Review Board Statement: Not applicable.

Informed Consent Statement: Not applicable.

Data Availability Statement: Data sharing not applicable.

Conflicts of Interest: The authors declare that they have no conflict of interest.

\section{References}

1. Yang, S.L.; Zhang, J.; Dai, S.B.; Li, M.; Xu, X.J. Effect of deposition and erosion within the main river channel and large lakes on sediment delivery to the estuary of the Yangtze River. J. Geophys. Res. 2007, 112, F02005. [CrossRef]

2. Heritage, G.; Entwistle, N. Impacts of River Engineering on River Channel Behaviour: Implications for Managing Downstream Flood Risk. Water 2020, 12, 1355. [CrossRef]

3. Thonon, I.; Middelkoop, H.; van der Perk, M. The influence of floodplain morphology and river works on spatial patterns of overbank deposition. Neth. J. Geosci. 2007, 86, 63-75. [CrossRef]

4. Corenblit, D.; Steiger, J.; Gurnell, A.M.; Tabacchi, E.; Roques, L. Control of sediment dynamics by vegetation as a key function driving biogeomorphic succession within fluvial corridors. Earth Surf. Proc. Land. 2009, 34, 1790-1810. [CrossRef]

5. Corenblit, D.; Steiger, J.; González, E.; Gurnell, A.M.; Charrier, G.; Darrozes, J.; Dousseau, J.; Julien, F.; Lambs, L.; Larrue, S.; et al The biogeomorphological life cycle of poplars during the fluvial biogeomorphological succession: A special focus on Populus nigra L. Earth Surf. Proc. Land. 2014, 39, 546-567. [CrossRef] 
6. Mayer, S.; Kölbl, A.; Völkel, J.; Kögel-Knabner, I. Organic matter in temperate cultivated floodplain soils: Light fractions highly contribute to subsoil organic carbon. Geoderma 2019, 337, 679-690. [CrossRef]

7. Suchara, I.; Sucharová, J.; Holá, M. Changes in selected physico-chemical properties of flooding soils in three different land-use types after flooding. Plant Soil Environ. 2021, 67, 99-109. [CrossRef]

8. Kordowski, J. The role of blocks of dead ice in the deposition of late glacial sediments in a large valley: A case study from the Vistula river valley in the Grudziądz Basin, north Poland. Geogr. Polon. 2013, 86, 341-361. (In Polish) [CrossRef]

9. Saint-Laurent, D.; Lavoie, L.; Drouin, A.; St-Laurent, J.; Chaleb, B. Floodplain sedimentation rates, soil properties and recent flood history in southern Quebec. Glob. Planet Chang. 2010, 70, 76-91. [CrossRef]

10. Wójcicki, K.J.; Marynowski, L. The organic and mineral matter contents in deposits infilling floodplain basins: Holocene alluviation record from the Kłodnica and Osobłoga river valleys, southern Poland. Geomorphology 2012, 159-160, 15-29. [CrossRef]

11. Bätz, N.; Verrecchia, E.P.; Lane, S.N. Organic matter processing and soil evolution in a braided river system. Catena 2015, 126, 86-97. [CrossRef]

12. Hoffmann, T.; Glatzel, S.; Dikau, R. A carbon storage perspective on alluvial sediment storage in the Rhine catchment. Geomorphology 2009, 108, 127-137. [CrossRef]

13. Davies-Vollum, K.S.; Smith, N.D. Factors affecting the accumulation of organic rich deposits in a modern avulsive floodplain: Examples from the Cumberland Marshes, Saskatchewan, Canada. J. Sediments Res. 2008, 78, 683-692. [CrossRef]

14. Marie, L.; Pernet-Coudrier, B.; Waeles, M.; Gabon, M.; Riso, R. Dynamics and sources of reduced sulfur, humic substances and dissolved organic carbon in a temperate river system affected by agricultural practices. Sci. Total Environ. 2015, 537, 23-32. [CrossRef]

15. Wendling, B.; Jucksch, I.; Mendonca, E.S.; Alvarenga, R.C. Organic-matter pools of soil under pines and annual cultures. Commun. Soil Sci. Plant Anal. 2010, 41, 1707-1722. [CrossRef]

16. Rumpel, K.; Kögel-Knabner, I. Deep soil organic matter-A key but poorly understood component of terrestrial C cycle. Plant Soil 2011, 338, 143-158. [CrossRef]

17. Guimarães, D.V.; Gonzaga, M.I.S.; Silva, T.O.; Silva, T.L.; Dias, N.S.; Matias, M.I.S. Soil organic matter pools and carbon fractions in soil under different land uses. Soil Till. Res. 2013, 126, 177-182. [CrossRef]

18. Zech, W.; Senesi, N.; Guggenberger, G.; Kaiser, K.; Lehmann, J.; Miano, T.M.; Miltner, A.; Schroth, G. Factors controlling humification and mineralization of soil organic matter in the tropics. Geoderma 1997, 79, 117-161. [CrossRef]

19. Lal, R. Soil C sequestration to mitigate climate change. Geoderma 2004, 123, 1-22. [CrossRef]

20. Schmidt, M.W.I.; Torn, M.S.; Abiven, S.; Dittmar, T.; Guggenberger, G.; Janssens, A.I.; Kleber, M.; Kogel-Knabner, I.; Lehmann, J.; Manning, A.C.D.; et al. Persistence of soil organic matter as an ecosystem property. Nature 2011, 478, 49-56. [CrossRef]

21. Tan, K.H. Humic Matter in Soil and the Environment: Principles and Controversies; Dekker: New York, NY, USA, 2014.

22. Lal, R. Soil Carbon Sequestration in Latin America. In Carbon Sequestration in Soils of Latin America; Lal, R., Cerri, C.C., Bernoux, M., Etcheves, J., Cerri, E., Eds.; Food Products Press: New York, NY, USA, 2006; pp. 49-64.

23. Orsi, M. Molecular dynamics simulation of humic substances. Chem. Biol. Technol. Agric. 2014, 1, 10. [CrossRef]

24. Weber, J.; Chen, Y.; Jamroz, E.; Miano, T. Preface: Humic substances in the environment. J. Soils Sediments 2018, 18, 2665-2667. [CrossRef]

25. Hayes, M.H.B.; Clapp, C.E. Humic substances: Consideration of compositions, aspects of structure and environmental influences. Soil Sci. 2001, 166, 723-737. [CrossRef]

26. Hayes, M.H.B.; Swift, R.S. Vindication of humic substances as a key component of organic matter in soil and water. Adv. Agron. 2020, 163, 1-37. [CrossRef]

27. Sutton, R.; Sposito, G. Molecular structure in soil humic substances: New view. Environ. Sci. Technol. 2005, 39, 9009-9016. [CrossRef]

28. Tejeda-Agredano, M.C.; Mayer, P.; Ortega-Calvo, J.J. The effect of humic acids on biodegradation of polycyclic aromatic hydrocarbons depends on the exposure regime. Environ. Pollut. 2014, 184, 435-442. [CrossRef]

29. Kobayashi, T.; Sumida, H. Effects of humic acids on the sorption and bioavailability of pyrene and 1,2-dihydroxynaphthalene. Soil Sci. Plant Nutr. 2015, 61, 113-122. [CrossRef]

30. Ćwieląg-Piasecka, I.; Medyńska-Juraszek, A.; Jerzykiewicz, M.; Dębicka, M.; Bekier, J.; Jamroz, E.; Kawałko, D. Humic acid and biochar as specific sorbents of pesticides. J. Soils Sediments 2018, 18, 2692-2702. [CrossRef]

31. Fooken, U.; Liebezeit, G. An IR study of humic acids isolated from sediments and soils. Senck. Marit. 2003, 32, 183-189. [CrossRef]

32. Gołębiowska, D.; Osuch, M.; Mielnik, L.; Bejger, R. Optical characteristics of humic acids from bottom sediments of lakes with different mictic types. EJPAU 2005, 8, 27.

33. Rodríguez, F.J.; Schlenger, P.; García-Valverde, M. Monitoring changes in the structure and properties of humic substances following ozonation using UV-Vis, FTIR and H NMR techniques. Sci. Total Environ. 2016, 541, 626-637. [CrossRef] [PubMed]

34. Derrien, M.; Lee, Y.K.; Park, J.E.; Li, P.; Chen, M.; Lee, S.H.; Lee, S.H.; Lee, J.B.; Hur, J. Spectroscopic and molecular characterization of humic substances (HS) from soils and sediments in a watershed: Comparative study of HS chemical fractions and the origins. Environ. Sci. Pollut. Res. Int. 2017, 24, 16933-16945. [CrossRef] [PubMed]

35. Yamashita, Y.; Jaffe, R.; Maie, N.; Tanoue, E. Assessing the dynamics of dissolved organic matter (DOM) in coastal environments by excitation emission matrix fluorescence and parallel factor analysis (EEM-PARAFAC). Limnol. Oceanogr. 2008, 53, 1900-1908. [CrossRef] 
36. Canellas, L.P.; Piccolo, A.; Dobbss, L.B.; Spaccini, R.; Olivares, F.L.; Zandonadi, D.B.; Façanha, A.R. Chemical composition and bioactivity properties of size-fractions separated from a vermicompost humic acid. Chemosphere 2010, 78, 457-466. [CrossRef]

37. Lanyi, K. Assessment of the relations between the spectroscopic characteristics of soils and their ability to adsorb organic pollutants. Microchem. J. 2010, 79, 249-256. [CrossRef]

38. Kumada, K. Chemistry of Soil Organic Matter; Elsevier: Amsterdam, The Netherlands, 1988.

39. Chen, J.; Gu, B.; LeBoeuf, E.; Pan, H.; Dai, S. Spectroscopic characterization of the structural and functional properties of natural organic matter fractions. Chemosphere 2002, 48, 59-68. [CrossRef]

40. Weishaar, J.L.; Aiken, G.R.; Bergamaschi, B.A.; Fram, M.S.; Fujii, R.; Mopper, K. Evaluation of specific ultraviolet absorbance as an indicator of the chemical composition and reactivity of dissolved organic carbon. Environ. Sci. Technol. 2003, 37, 4702-4708. [CrossRef]

41. Morán Vieyra, F.E.; Palazzi, V.I.; Sanchez de Pinto, M.I.; Borsarelli, C.D. Combined UV-Vis absorbance and fluorescence properties of extracted humic substances-like for characterization of composting evolution of domestic solid wastes. Geoderma 2009, 151, 61-67. [CrossRef]

42. Polak, J.; Bartoszek, M.; Żąło, M.; Kos, A.; Sułkowski, W.W. The spectroscopic studies of humic acid extracted from sediment collected at different seasons. Chemosphere 2011, 84, 1548-1555. [CrossRef]

43. Woelki, G.; Friedrich, S.; Hanschmann, G.; Salzer, R. HPLC fractionation and structural dynamics of humic acids. Fresen. J. Anal Chem. 1997, 357, 548-552. [CrossRef]

44. Preuße, G.; Friedrich, S.; Salzer, R. Retention behavior of humic substances in reversed phase HPLC. Fresen. J. Anal. Chem. 2000, 368, 268-273. [CrossRef] [PubMed]

45. Dębska, B.; Drag, M.; Banach-Szott, M. Molecular size distribution and hydrophilic and hydrophobic properties of humic acids isolated from forest soil. Soil Water Res. 2007, 2, 45-53. [CrossRef]

46. Dębska, B.; Banach-Szott, M.; Dziamski, A.; Gonet, S.S. Chromatographic characteristics (HPLC, HPSEC) of humic acids of soil fertilised with various organic fertilisers. Chem. Ecol. 2010, 26, 49-57. [CrossRef]

47. Dębska, B.; Drag, M.; Tobiasova, E. Effect of post-harvest residue of maize, rapeseed, and sunflower on humic acids properties in various soils. Pol. J. Environ. Stud. 2012, 21, 603-613.

48. Daniels, J.M. Floodplain aggradation and pedogenesis in a semiarid environment. Geomorphology 2003, 56, 225-242. [CrossRef]

49. Kobierski, M.; Kondratowicz-Maciejewska, K.; Banach-Szott, M.; Wierzowiecki, M. Sorptive properties of cultivated Fluvisols between Vistula river-bed and flood embankment from Unislaw Basin. Roczn. Glebozn. 2010, 61, 97-104. (In Polish)

50. Dębska, B.; Długosz, J.; Piotrowska-Długosz, A.; Banach-Szott, M. The impact of bio-fertilizer on the soil organic matter status and carbon sequestration-results from a fiel-scale study. J. Soil. Sediments 2016, 16, 2335-2343. [CrossRef]

51. Kondratowicz-Maciejewska, K.; Banach-Szott, M.; Kobierski, M. Physicochemical properties of humic acids of Fluvisols from Unisław Basin. Roczn. Glebozn. 2010, 61, 123-127. (In Polish)

52. Banach-Szott, M.; Kobierski, M.; Kondratowicz-Maciejewska, K. Humic substances in Fluvisols of the Lower Vistula floodplain, North Poland. Environ. Sci. Pollut. Res. 2018, 25, 23999-24002. [CrossRef]

53. Rosa, E.; Dębska, B.; Banach-Szott, M.; Tobiasova, E. Use of HPLC, py-GCMS, FTiR methods in the studies of the composition of soil dissolved organic matter. Pol. J. Soil Sci. 2015, 48, 101-110. [CrossRef]

54. Kobierski, M.; Kondratowicz-Maciejewska, K.; Banach-Szott, M.; Wojewódzki, P.; Peñas Castejón, J.M. Humic substances and aggregate stability in rhizospheric and non-rhizospheric soil. J. Soils Sediments 2018, 18, 2777-2789. [CrossRef]

55. Simansky, V. Can soil properties of Fluvisols be influenced by river flow gradient? Acta Fytotechn. Zootechn. 2018, 21, 63-76. [CrossRef]

56. Anger, D.A.; Bissonette, N.; Legere, A.; Samson, N. Microbial and biochemical changes induced by rotation and tillage in a soil under barley production. Can. J. Soil Sci. 1993, 73, 39-50. [CrossRef]

57. Smreczak, B.; Ukalska-Jaruga, A. Dissolved organic matter in agricultural soils. Soil Sci. Ann. 2021, 72, 132234. [CrossRef]

58. Watanabe, A.; Rumbanraja, J.; Tsutsuki, K.; Kimura, M. Humus composition of soils under forest, coffee and arable cultivation in hilly areas of south Sumatra, Indonesia. Eur. J. Soil Sci. 2001, 52, 599-606. [CrossRef]

59. Drag, M.; Dębska, B.; Dziamski, A. Properties of humic substances of forest and meadow soil in the area of the Wierzchlas Reserve. Humic Subst. Ecosyst. 2007, 7, 141-151.

60. Becher, M.; Banach-Szott, M.; Godlewska, A. Organic matter properties of spent button mushroom substrate in the context of soil organic matter reproduction. Agronomy 2021, 11, 204. [CrossRef]

61. Tinoco, P.; Almendros, G.; Gonzalez-Vila, F.J.; Sanz, J.; Gonzalez-Perez, J.A. Revisiting molecular characteristics responsive for the aromaticity of soil humic acids. J. Soils Sediments 2015, 15, 781-791. [CrossRef]

62. Filcheva, E.; Hristova, M.; Nikolova, P.; Popova, T.; Chakalov, K.; Savov, V. Quantitative and qualitative characterisation of humic products with spectral parameters. J. Soil Sediments 2018, 18, 2863-2867. [CrossRef]

63. Albrecht, R.; Petit, J.L.; Terrom, G.; Périssol, C. Comparison between UV spectroscopy and Nirs to assess humification process during sewage sludge and green wastes co-composting. Bioresour. Technol. 2011, 102, 4495-4500. [CrossRef] 